УДК 373.2.015.31

DOI:

Леся Перхун, кандидат педагогічних наук, доцент кафедри загальної педагогіки та дошкільної освіти Дрогобицького державного педагогічного університету імені Івана Франка Мар'яна Клим, кандидат педагогічних наук, доцент кафедри соціальної педагогіки та корекиійної освіти Дрогобицького державного педагогічного університету імені Івана Франка

\title{
РОЗВИТОК ТВОРЧОСТІ ДІТЕЙ ДОШКІЛЬНОГО ВІКУ ЗАСОБАМИ КАЗКИ, ІНСЦЕНІЗОВАНОЇ У ГРІ У СЕРЕДОВИЩІ ЗАКЛАДІВ ДОШКІЛЬНОЇ ОСВІТИ
}

У статті окреслено особливості розвитку творчості дітей дошкільного віку через інсценізацію казки в ігровій діяльності. Встановлено, щчо ігрова діяльність є запорукою кращого пізнання сочіального світу, а творчість показує рівень ї̈ розвитку, а також є фактором, щзо стимулює подальший розвиток дошкільника. За допомогою казки розвивається увага та проникливість, збагачується словниковий запас, розиирюється інформація про навколишній світ. Вихователь, використовуючи казки, надихає дитину на подальший пошук та формування творчої позищії. 3'ясовано, щуо динамічний інтелектуальний розвиток провокує потребу в нових знаннях.

Ключові слова: творчість; діти дошкільного віку; ігрова діяльність; інсценізачія; заклади дошкільної освіти.

Jim. 9.

Lesya Perkhun, Ph.D.(Pedagogy), Associate Professor of the General Pedagogy and Preschool Education Department of Drohobych Ivan Franko State Pedagogical University Mariana Klym, Ph.D.(Pedagogy), Associate Professor of the Social Pedagogy and Correctional Education Department of Drohobych Ivan Franko State Pedagogical University

\section{DEVELOPMENT OF PRESCHOOL CHILDREN CREATIVITY BY MEANS OF A FAIRY TALE, STAGEED IN A GAME IN THE ENVIRONMENT OF PRESCHOOL EDUCATIONALINSTITUTIONS}

The article deals with the peculiarities of the development of creativity of preschool children via the staging of a fairy tale in the play activities. It is established that play activities are the key to better knowledge of the social world and creativity, showing the level of its development and is a factor that stimulates further development of the preschooler. With the help of a fairy tale, attention and insight develop, vocabulary is enriched, information about the world around is expanded. Using fairy tales, the educator inspires the child to further search and form a creative position. Peculiarities of staging a fairy tale has been outlined.

It has been found that dynamic intellectual development provokes the need for new knowledge. During this period, there is an ability to memorize and use fixed information appears. The child is able to combine the heard information with his own experience, to tell simple stories. Based on reading habits implemented by adults, a preschool child has been fascinated by fairy tales. At this time there is also an interest in words and letters, a willingness to learn to read. Preschool age is of fundamental importance for the development of children's cognitive processes and the formation of the foundations of their creativity. Children at this age form the first value orientations, the child adopts the first norms, patterns and ideals of behavior.

It is established that fairy tales have the ability to influence the process of education and development of the child's personality, because the fairy tale inspires the child to perform some action and be active. In this way, preschool children identify themselves with the protagonist, learn to recognize their emotions and feelings. A source of vivid impressions, an indispensable way to enrich the imagination and interest in the world, children's literature for preschoolers, namely fairy tales. We studied that in the content of a fairy tale in dramatic form and in the form of a game has a strong influence on the experiences and emotions of students, each child experiences fictional situations shown in fairy tales, identifies himself with the characters.

Keywords: creativity; preschool children; game activity; staging; preschool educational institutions.

П остановка проблеми. Комплексний розвиток дитини в дошкільний період істотно впливає на оволодіння нею базовими навичками - письма, говоріння та читання. Розвиток інтелектуальних процесів дає змогу отримувати й обробляти інформацію. У 


\section{РОЗВИТОК ТВОРЧОСТІ ДІТЕЙ ДОШКІЛЬНОГО ВІКУ ЗАСОБАМИ КАЗКИ, ІНСЦЕНІЗОВАНОӤ У ГРІ У СЕРЕДОВИЩІ ЗАКЛАДІВ ДОШКІЛЬНОӤ ОСВІТИ}

міру зростання самостійності та інтелектуального розвитку дитини сфера їі інтересів також розширюється, все більше і більше виходячи за межі найближчого соціального оточення. Результатом є постійний прогрес у розумовому, фізичному та творчому розвитку. У контексті змін, що відбуваються на рівні психічного розвитку і пов'язані з когнітивними процесами, ключове значення має творчий розвиток, саме тому йому приділяється значна увага.

Творча діяльність допомагає дитині ближче пізнати навколишній світ, його властивості, елементи, соціальні відносини. Завдяки цьому вона будує своє місце у світі. Творча діяльність $€$ проявом рівня її розвитку, а також фактором, що стимулює подальший розвиток. За допомогою казки тренуються увага та проникливість, збагачується словниковий запас, розширюється і консолідується інформація про навколишній світ. Вихователь, використовуючи казки, надихає дитину на подальший пошук та формування творчої позиції. Розвиток творчості у дитини вимагає того, щоб надати їй можливість діяти творчо, оскільки вона вчиться запам'ятовувати і використовувати свої знання через казку.

Аналіз останніх досліджень і публікацій. Особливості розвитку дитячої творчості у середовищі закладів дошкільної освіти досліджено у працях Г. Бєлєнької, О. Василевської, М. Замелюк. У наукових працях здійснено пошук найбільш універсальних засобів та методів розвитку творчості дітей дошкільного віку, які впливають на процес соціалізації особистості. Теоретико-практичні основи творчої діяльності дітей дошкільного віку окреслено у доробках О. Білан, О. Демченко, Г. Лопатіної, Т. Піроженко. У них акцентовано увагу на тому, що першочерговим завданням вихователя закладу дошкільної освіти є креативний розвиток засобами ігрової діяльності.

Мета статті - проаналізувати особливості формування творчості дітей дошкільного віку засобами казки, яка інсценізована через гру в умовах освітньої діяльності закладів дошкільної освіти.

Виклад основного матеріалу дослідження. Важливу роль у створенні умов для розвитку творчої діяльності дитини дошкільного віку відіграє вихователь. Саме він має змогу організувати розвиток творчості дітей різними засобами, наприклад, літературними текстами, музикою, казками. Для дітей у цьому віці важливий не стільки результат їхньої діяльності, скільки сам процес створення та власне діяльність, пов'язана з цим. Вихователь виступає як особистість, що спонукає до дії, пропонує різні поради $[2,24]$.

Постійні контакти дитини 3 ретельно підібраними казками формують у неї естетичну чутливість і водночас сприяють розвитку творчих установок, словесного та художнього вираження. Відомі казки дають тему для реалізації театралізованих ігор, створюють значні можливості для розвитку словесної винахідливості дитини. Тому в кожному класі закладу дошкільної освіти повинен бути театральний куточок 3 різними видами ляльок, реквізитів казки, сцен, які заохочують драматичну діяльність.

Науковці зазначають, що, починаючи 3 дитячого садка, дітей слід вводити до активного та сміливого подолання проблем, які, викликаючи творчу чи дослідницьку позицію, уможливлять формування бажаних духовних і матеріальних цінностей. Казки відіграють дуже важливу роль. Ці твори впливають на виховання та розвиток особистості дитини, спонукають її до фантазування та надихають самостійно здійснити якусь дію, бути активною творчо. Слухаючи казки, діти дошкільного віку часто ототожнюють себе з головними героями $[4 ; 6 ; 8]$.

У концепції Гілфорда виокремлюється дивергентне мислення, яке відповідальне за творчість. Саме воно відповідає за слова, фрази, ідеї, рішення тощо. У цій концепції виокремлено також гнучкість мислення, яке полягає у здатності виробляти ідеї різної якості. У руслі цієї концепції вважаємо, що саме казка може розвивати такий вид мислення $[6,17]$.

Т. Піроженко розглядає творчість як одну зі змістовних форм психічної активності дитини, певну універсальну здібність, яка має на меті забезпечити успіх діяльності дітей дошкільного віку. “Засвоєння дитиною мови є творчим процесом, гра - теж творчість, оскільки створюючи нові ігрові ситуації, дитина вносить свій внесок в ігрові дії, зображувальну, театральну діяльність тощо. Нові знання трансформуються кожною дитиною i набувають нових властивостей” $[9,23]$.

Науковець О. Демченко аналізує творчість у роботі з казкою з дітьми дошкільного віку, обгрунтовуючи ідею про те, що це має бути: аналітичний, або дослідницький процес, на якому аналізується зміст казки; оперативний або творчий етап, який передбачає коригування дітьми за допомогою педагога деяких якостей персонажів чи інших об'єктів казки з метою розв'язання певних проблем; синтетичний, або впровадження ідей, що передбачає повне перероблення змісту казки 3 попереднім 


\section{РОЗВИТОК ТВОРЧОСТІ ДІТЕЙ ДОШКІЛЬНОГО ВІКУ ЗАСОБАМИ КАЗКИ, ІНСЦЕНІЗОВАНОӤ У ГРІ У СЕРЕДОВИЩІ ЗАКЛАДІВ ДОШКІЛЬНОЇ ОСВІТИ}

3'ясуванням наслідків, які спричинить новий зміст для врегулювання казкового конфлікту [5, 82].

Твори дитячої літератури, а серед них $\mathbf{i}$ казки, можна по-різному використовувати: як творчі ігри чи акторські інсценізації, коли окремі ролі виконують діти або різні види лялькових вистав, в яких грають ляльки, фігури і навіть іграшки, а діти у цьому процесі є їхніми аніматорами $[3,17]$.

Перегляд малюнків у казках є важливим фактором розвитку мовлення та мислення. Відомі казки сприяють постановці театралізованих ігор, не вимагаючи використання слів тексту, вони створюють великі можливості для розвитку словесної винахідливості дитини. Тому в кожному класі дитячого садка повинен бути театральний куточок з різними видами ляльок, реквізиту, сцен [4, 32-33].

У науковій літературі стверджується, що розвивати творчі здібності дитини найкраще 3 дошкільного віку. Однак не слід забувати, що творчість дітей починається раніше, з вироблення окремого способу мислення та вирішення проблем. У цьому контексті можна підібрати таку навчальну вправу. Вихователь розповідає малюкові казку, повністю вигадану. Через 2-3 речення пропонує дитині придумати продовження. Таким чином, дошкільники обмінюються думками 3 вихователем кожні кілька речень, створюючи все більш дивовижну та повчальну історію $[1,27]$.

Доцільно застосувати також інценізацію казки через гру, саме тому вважаємо за доцільне розглянути деякі 3 них. Навчальна гра “Міжпланетна мандрівка Маленького принца", організована на основі твору А. де Сент-Екзюпері сприяє розвитку творчості. Розглянемо ігрові прийоми: планета смішних кроків - всі роблять поїзд, рухаються під музику; шоколадна планета - вихователь дарує шоколад дітям; планета воюючих племен - діти виконують сидячий танець; планета мовчазних племен - кожному доручено описати своє ім'я за допомогою жестів; планета моєї мрії - дитина придумує назву своєї планети мрії.

Особливе значення має організація навчальної гри “Розваги в зоопарку”. Діти в групах із трьох учасників наслідують тварин: слон - дитина, що стоїть по середині робить хобот, інші - два вуха; жираф - середні руки вгору, бічні вуха; верблюд - дитина, що стоїть по середині нахиляється вперед, робить горби на спині; риба - дитина, що стоїть по середині нахиляється вперед і рухає ротом, а діти знаходяться з лівого та правого боку зображують плавники.
Розвиток творчості зумовлений також використанням гри “Ретушування портретів" та "Геометрія в місті". Кожна дитина отримує портрет. Завдання для дитини - охарактеризувати портрет за власною ідеєю, намалювавши волосся, веснянки, окуляри. Завданням гри "Геометрія в місті” є зробити дошку, що ілюструє місто. Можна використовувати лише геометричні фігури квадратної форми. Циркова геометрія використовуються лише кола. Геометрія в просторі - можна використовувати лише трикутники. Геометрія в лісі-прямокутники.

У реалізації гри “Казкова естафета" вихователь ділить дітей на групи. Він розкладає на столі кілька карток із казковими героями. Гра в групах відбувається у такий спосіб: перша дитина вибирає одну карту і формує речення, наприклад - “гном, блукаючи лісом, зустрів прекрасну принцесу”. Потім дитина повторює це речення та формує наступне. Одночасно вихователь показує картку своєму колезі. Інша дитина повторює запам'ятований зміст та продовжує розповідь. У кінці гри кожна група представляє свою авторську казку.

Навчальна гра "Чарівні окуляри" обумовлюється тим, що діти сидять в колі. Вихователь починає гру з того, що розповідає: “Якби мені сьогодні подарували чарівні окуляри, я б хотів, щоб усі дерева i рослини були помаранчевими, а квіти цвіли лише білим кольором. А що б ви хотіли змінити, якби у вас були такі чарівні окуляри?” Вихователь подає талісман хлопчикові, він повинен швидко встати, схопити талісман і щось сказати. Наступні діти, які отримують талісман, не можуть використовувати ідеї, які вже подані. Кожна дитина повинна використати талісман принаймні один раз [7; 8].

Навчальна гра "Ми відкриваємо для себе світ" - промальовування дивної дороги, де дошкільники зустрічають дивні речі, тварин та людей. Діти слухають історії про чарівника, який подарував їм семимильні черевики, завдяки яким вони можуть швидко досліджувати світ, навіть його найдивніші куточки.

Цікавим також видається планування гри “Покупки”. На столах для дітей готують різнокольорові газети, шматки пряжі, конверти формату A4, клей, ножиці. Завдання дітей виготовити сумку та зробити покупки в магазині, вирізати та наклеїти на сумку все, що було куплено. Згодом дошкільнята розповідають про зроблені покупки.

Висновки. Казки впливають на виховання та розвиток особистості дитини, спонукають дітей до фантазування, надихають самостійно 


\section{РОЗВИТОК ТВОРЧОСТІ ДІТЕЙ ДОШКІЛЬНОГО ВІКУ ЗАСОБАМИ КАЗКИ, ІНСЦЕНІЗОВАНОЇ У ГРІ У СЕРЕДОВИЩІ ЗАКЛАДІВ ДОШКІЛЬНОЇ ОСВІТИ}

здійснити якусь дію, бути активною. Слухаючи ці твори, діти дошкільного віку ототожнюють себе 3 головним героєм, таким чином навчаючись розпізнавати свої емоції та почуття. Джерелом яскравих вражень, незамінним способом збагачення уяви та зацікавлення до навколишнього світу дитяча література для дошкільного віку, а саме казки, інценізовані у грі. Це створює можливості для творчої діяльності. Відтворення змісту казки в драматичній формі має сильний вплив на переживання та емоції, кожна дитина переживає вигадані ситуації, показані в казках, ототожнює себе 3 героями та бере участь у їхніх пригодах.

Перспективним напрямом подальших наукових досліджень $є$ аналіз особливостей впливу казки на формування стереотипів поведінки та самоідентифікації дитини у контексті вітчизняного і зарубіжного досвіду.

\section{ЛІТЕРАТУРА}

1. Арнаудов М. Психологія літературної творчості. Москва: Прогрес, 2007. 654 с.

2. Бєлєнька Г. Вихователь дітей дошкільного віку: становлення фахівця в умовах навчання. Київ: Світоч, 2006. 304 с.

3. Білан О., Возна Л., Максименко О. Українське дошкілля: програма виховання та навчання дітей у дошкільних закладах. Тернопіль: Мандрівець, 2012. 264 с.

4. Василевська О. І. Казкотерапія як засіб психолого-педагогічного впливу. Науковий часопис НПУ імені М. П. Драгоманова. Серія 12: Психологічні науки. 2012. Вип. 39. С. 30-36.

5. Демченко О. Особливості створення вербальних виховних ситуацій за змістом казок у роботі $з$ дошкільнятами. Гуманізація навчальновиховного процесу: збірник наукових праць. Ч.1. Словянськ: СДПУ, 2010. С.81-88.

6. Замелюк М. Готовність майбутнього вихователя до реалізації творчого потенціалу дошкільника засобами авторської казки: цілемотиваційний компонент. Педагогічна майстерність: методологія, теорія, технології. Черкаси. 2015. С. 15-17.

7. Замелюк М. Сучасний вихователь креативна особистість. Дочкільне виховання. №5. 2013. С. 13.

8. Лопатіна Г. О. Художнє слово як засіб навчання діалогічного мовлення дітей молодшого дошкільного віку. Педагогічна освіта: теорія $i$ практика. 2011. Вип. 8. С. 227-231.

9. Піроженко Т., Ладивір С., Біла I. Дитина у сучасному соціопросторі. Навчальний посібник. Кіровоград: Імекс-ЛТД, 2014. 272 с.

\section{REFERENCES}

1. Arnaudov M. (2007). Psykholohiia literaturnoi tvorchosti [Psychology of literary creativity]. Moskow, 54 p. [in Ukrainian].

2. Bielienka, H. (2006). Vykhovatel ditei doshkilnoho viku: stanovlennia fakhivtsia $v$ umovakh navchannia [Educator of preschool children: becoming a specialist in the learning environment]. Kyiv, 304 p. [in Ukrainian].

3. Bilan, O., Vozna, L. \& Maksymenko, O. (2012). Ukrainske doshkillia: prohrama vykhovannia ta navchannia ditei u doshkilnykh zakladakh [Ukrainian preschool: the program of education and training of children in preschool institutions]. Ternopil, $264 \mathrm{p}$. [in Ukrainian].

4. Vasylevska, O. (2012). Kazkoterapiia yak zasib psykholoho-pedahohichnoho vplyvu [Fairy tale therapy as a means of psychological and pedagogical influence]. Drahomanov NPU Scientific journal. Series 12: Psychological Sciences. issue. 39. pp. 3036. [in Ukrainian].

5. Demchenko, O. (2010). Osoblyvosti stvorennia verbalnykh vykhovnykh sytuatsii za zmistom kazok u roboti $z$ doshkilniatamy [Features of creating verbal educational situations on the content of fairy tales in working with preschoolers]. Humanization of the educational process: a collection of scientific papers. Part 1. Sloviansk, pp.81-88. [in Ukrainian].

6. Zameliuk, M. (2015). Hotovnist maibutnoho vykhovatelia do realizatsii tvorchoho potentsialu doshkilnyka zasobamy avtorskoi kazky: tsilemotyvatsiinyi komponent [Readiness of the future educator to realize the creative potential of the preschooler by means of the author's fairy tale: purposeful component]. Pedagogical skills: methodology, theory, technologies. Cherkasy, pp. 1517. [in Ukrainian].

7. Zameliuk, M. (2013). Suchasnyi vykhovatelkreatyvna osobystist [Modern educator - a creative person]. Preschool education. No. 5. p. 13. [in Ukrainian].

8. Lopatina, H. (2011). Khudozhnie slovo yak zasib navchannia dialohichnoho movlennia ditei molodshoho doshkilnoho viku [Art word as a means of teaching dialogic speech to children of primary school age]. Pedagogical education: theory and practice. 2011. issue 8. pp. 227-231. [in Ukrainian].

9. Pirozhenko, T., Ladyvir, S. \& Bila, I. (2014). Dytyna u suchasnomu sotsioprostori [The child in the modern socio-space]. Kirovograd, p. 272. [in Ukrainian].

Стаття надійшла до редакції 25.03.2021 